\title{
SPP2019
}

Lucyna Wachecka-Kotkowska*, Dariusz Krzyszkowski, Dariusz Wieczorek, Steven Boswell, and Elżbieta Myśkow

\section{Lithopetrographic and geochemical features of the Saalian tills in the Szczerców outcrop (Poland) in various deformation settings}

https://doi.org/10.1515/geo-2020-0186

received February 03, 2020; accepted July 21, 2020

\begin{abstract}
This paper presents the results of new studies of Saalian tills, from the Ławki and Rogowiec formations, filling the Kleszczów Graben. The study area is located in the Szczerców outcrop, Bełchatów Lignite Opencast Mine, central Poland. Laboratory studies included macrofossil analysis of the deposits, as well as petrographic and geochemical (neodymium isotope ratio) measurements. The studies were carried out in 2014-2016 and resulted in both establishing the sedimentary Saalian complex and constructing geological cross-sections and a synthetic lithostratigraphic profile. Development of sediments in this part of the Kleszczów Graben in the Pleistocene was largely influenced by tectonic factors (Chabielice fault, Dębina Salt Dome) and glacitectonic processes (Wartanian Glaciation). The Saalian tills (T4 - Ławki and T7 - Rogowiec lithotypes) are between the Holsteinian sand with macroremnants of trees and the Eemian gyttja and peat. Petrographic coefficients for lithotype T4 (Eawki Formation) are 1.33-1.06-1.01 and 0.12 and for lithotype T7 (Rogowiec Formation) are
\end{abstract}

\footnotetext{
* Corresponding author: Lucyna Wachecka-Kotkowska, Department of Geology and Geomorphology, Faculty of Geographical Sciences, University of Łódź, Narutowicza 88, Łódź, 90-139, Poland, e-mail: lucyna.wachecka@geo.uni.lodz.pl

Dariusz Krzyszkowski: Institute of Geography and Regional Development, University of Wroctaw, Pl. Uniwersytecki 1, Wroctaw, 50-137, Poland, e-mail: dariusz.krzyszkowski@uwr.edu.pl Dariusz Wieczorek: Polish Geological Institute - National Research Institute, Holy Cross Branch of Jan Czarnocki, Zgoda 21 St., Kielce, 25-953, Poland, e-mail: dwie@pgi.gov.pl

Steven Boswell: Columbia University, Lamont-Doherty Earth Observatory, 61 Route 9W, Palisades New York, 10964, USA, e-mail: smb2258@caa.columbia.edu

Elżbieta Myśkow: University of Wrocław, Institute of Experimental Biology, Kanonia 6/8, Wrocław, 50-328, Poland,

e-mail: elzbieta.myskow@uwr.edu.pl

ORCID: Lucyna Wachecka-Kotkowska 0000-0002-5440-6300; Dariusz Krzyszkowski 0000-0003-4451-2051; Dariusz Wieczorek 0000-0001-6612-5349; Steven Boswell 0000-0003-0419-0836; Elżbieta Myśkow 0000-0001-6305-9681
}

1.29-1.23-1.04 and 0.12. Investigations of the $\mathrm{Nd}$ isotopic compositions of the studied samples reinforce our interpretations of till deformation and tentative lithostratigraphic correlations. Neodymium isotope ratios "P" $(-14.4 \pm 0.7)$ and "D" $(-12.4 \pm 0.3) \varepsilon_{\mathrm{Nd}}$ values $(2 \sigma)$ correspond to mean signatures of Saalian glacigenic moraine sediment. This proves that $\varepsilon_{\mathrm{Nd}}$ values less than -12.4 reflect the southern Fennoscandian Ice Sheet sediment provenance, but $\varepsilon_{\mathrm{Nd}}$ values greater than -12.4 indicate the western European origin.

Keywords: Pleistocene, Saalian, stratigraphy, glacial tills, petrography, Neodymium isotope, Szczerców outcrop, central Poland

\section{Introduction}

As the lignite in the Bełchatów and Szczerców outcrops is extracted using the opencast method (Figure 1), we are capable of tracing till horizons and their positions in the vertical section of Pleistocene deposits.

The investigations carried out during the last years have shown that the lithostratigraphic and chronostratigraphic subdivisions of the Bełchatów outcrop [1-4], which are also used for the Szczerców outcrop [5], do not correspond fully to the new subdivision established for the Polish Lowlands [6-8].

The lithology of Saalian deposits in the study area is relatively diverse. As the mining operations were progressing to the east, more and more intense effects of tectonic and glaciotectonic deformation of Pleistocene deposits were observed in the Szczerców outcrop. This is because of both the occurrence of the Chabielice fault and the influence of the Dębina Salt Dome (DSD) $[5,9,10]$. About $10-30 \mathrm{~km}$ to the south and south-east of the study area, there is the limit line of the Wartanian Glaciation [11-13] or the Wartanian Stadial $[14,15]$. The study area and adjacent areas (Szczerców Basin and the southern part of the Bełchatów Plateau) are considered as examples of classical development of ice-lobe relief of the Widawka lobe $[13,14,16,17]$. In the regions of Biała, Sulmierzyce, 


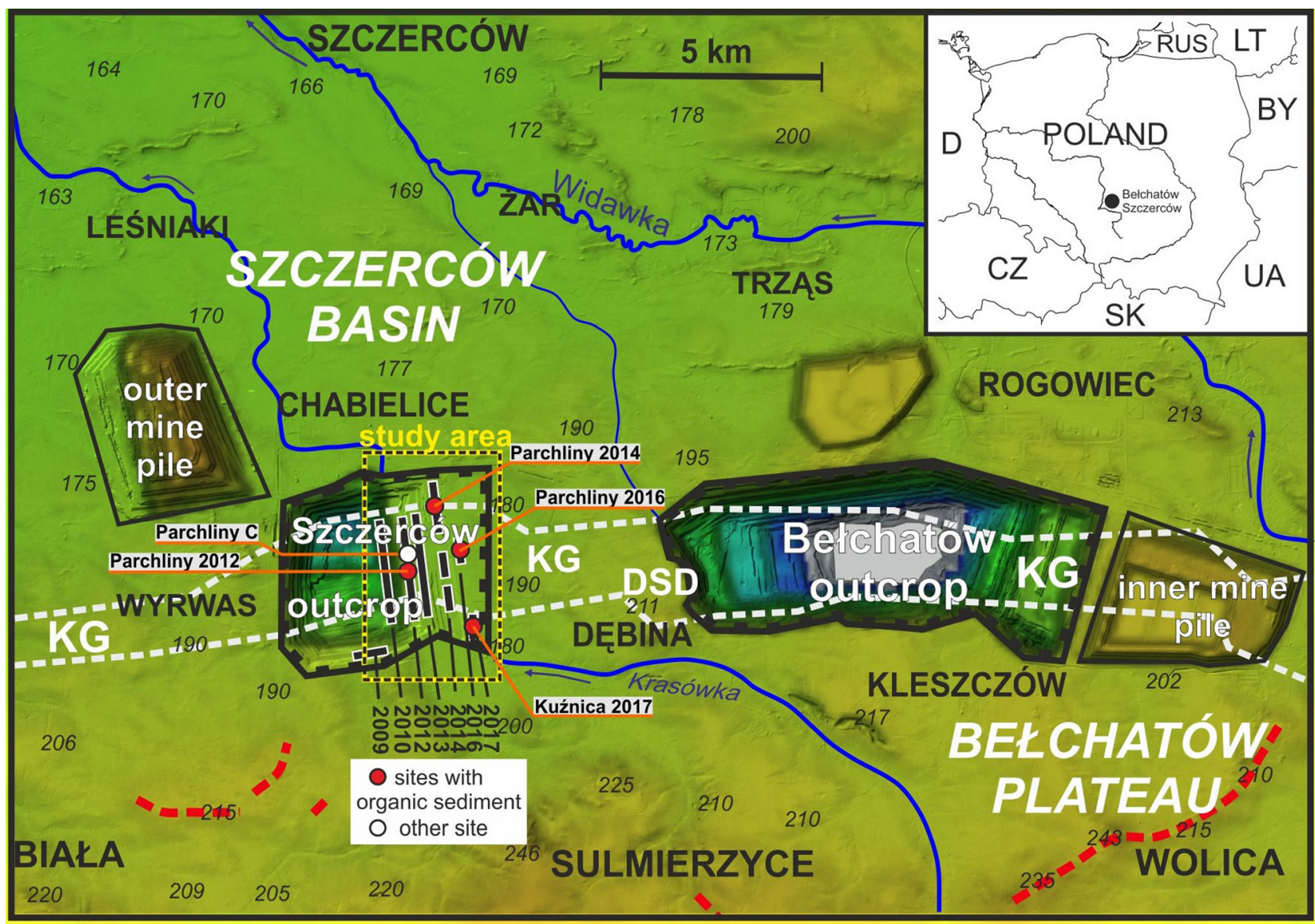

Figure 1: Study area against the background of the Betchatów Lignite Opencast Mine facilities and the surrounding relief. Elevations are in italics. Site with organic sediment: 2012 - "Parchliny 2012" (Early to Middle Eemian) and Parchliny C (Early Saalian); 2014 - "Parchliny 2014" (Eemian-Early to Middle Weichselian); 2016 - "Parchliny 2016” (Late Saalian to Early Eemian); KG - Kleszczów Graben (marked by white dashed line); DSD - Dębina Salt Dome.

and Wolica, there is a zone of frontal moraines, whereas toward the north, a zone of kettle lakes and holes extends (Figure 1).

\section{Geological setting}

Both (Bełchatów and Szczerców) outcrops are located within the Kleszczów Graben, which was active in the Neogene and Pleistocene [18]. Although a wide range of Pleistocene sections should be preserved in this area, they are not present. On one hand, the ice sheet advance and the stress that the ice exerts on the bedrock led to subsidence of the graben's floor, which favored accumulation of thick ice-dammed lake or glaciofluvial series [19] in two to three cycles [20]. On the other hand, mining operations in the Szczerców outcrop indicate a local significant reduction of the Pleistocene section. This is probably related to the location of the Chabielice fault and the DSD in this region [21].

In the last years, it was possible to make a comprehensive study of the following units: the Piaski Formation from the Middle and Late Weichselian [22], Aleksandrów Formation from the Late Saalian, Eemian Interglacial and Early Weichselian [23], and the Saalian complex: the Rogowiec Formation (T7, Wartanian) and tawki Formation (T4; Odranian) $[5,10,24,25]$ (see Table 1).

Tracing the horizons of mainly Saalian tills, from the Krasówka valley in the center of the outcrop toward the salt diapir (SDS) to the east, and against the Chabielice fault in the western sector of the Kleszczów Graben, was of foremost importance. Next, the role of tectonics, glaciotectonics, and halotectonics in the evolution of the graben's infill were studied in relation to the critical views and interpretation of the lithostratigraphic subdivision applied for the central part of the graben - the Bełchatów outcrop. 
Table 1: General stratigraphy of the Pleistocene deposits filling the Kleszczów Graben according to Krzyszkowski et al. [5,10,22,23,25]

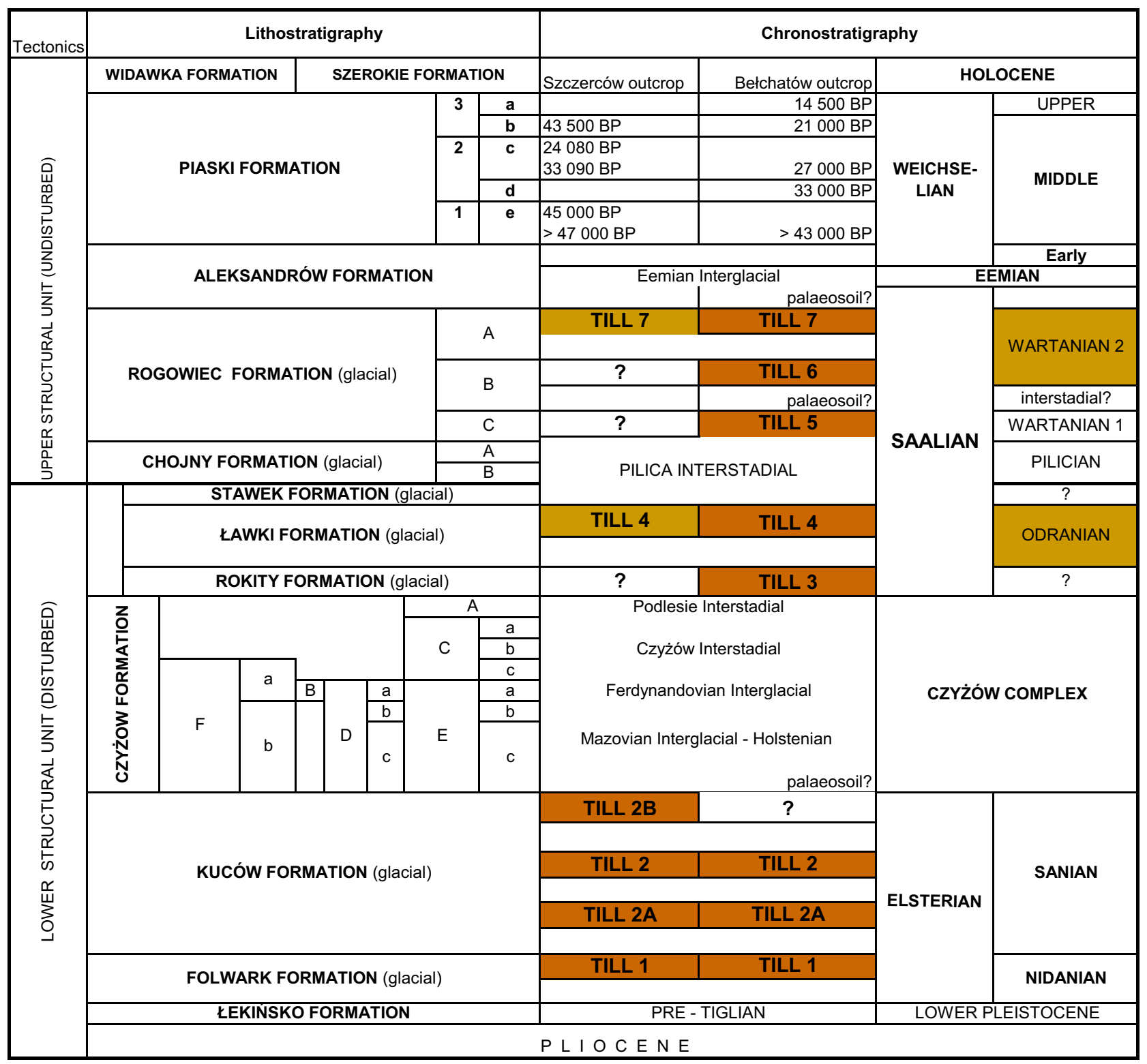

Petrographic features of the Saalian tills and neodymium isotope analyses were expected to help in the age interpretation of the tills found at the top of the Pleistocene deposits.

\section{Materials and methods}

\subsection{Fieldwork in outcrop}

The fieldwork mainly included lithological analyses, petrographic analyses, and macrofossil sampling of the deposits. They were exposed at mining levels I and II on the eastern wall (Figures 1-3). Glacial till samples were collected for lithopetrographic and geochemical analyses. Biological material was helpful for setting boundaries of the Saalian complex. In 2014, seven till samples were taken (Nos. 465-471), and further five samples (Nos. 461-464a,b) were taken in 2016. A geological cross-section of the eastern wall at mining levels I and II, and a detailed sketch of exposed deposits were compiled in 2014 and 2016 (Figure 2).

\subsection{Petrographic analysis}

Petrographic analysis of gravels from the tills was performed on the $5-10 \mathrm{~mm}$ fraction, according to the standard specified by the Polish Geological Institute - National Research Institute in Warsaw [26]. A population of gravels (preferably more 


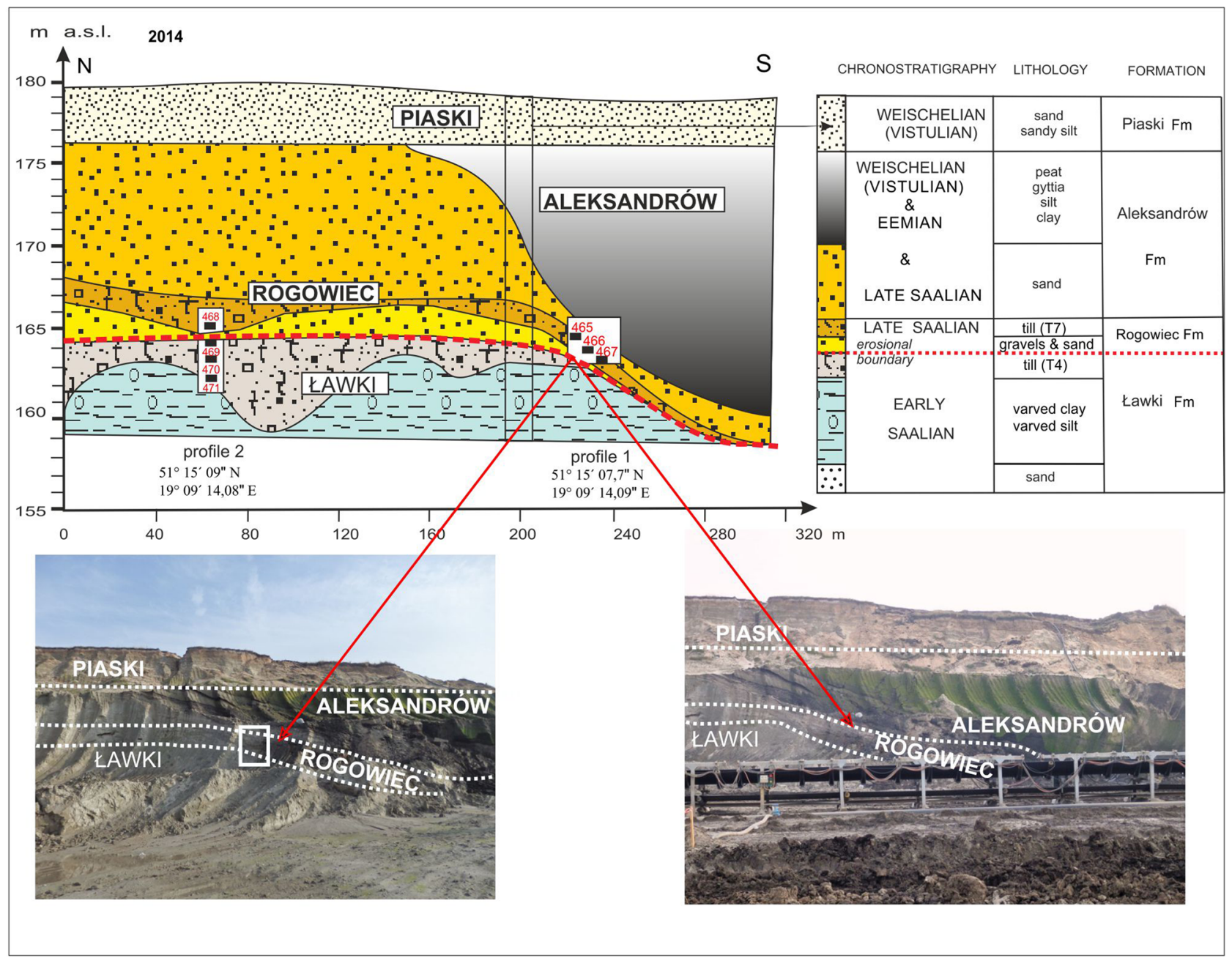

Figure 2: Geological cross-section of the Pleistocene sediments within the eastern part of the Szczerców outcrop (July 2014).

than 300 pieces) was divided into two groups. The first group included northern rocks from Scandinavia. The second one consisted of local rocks from the Polish Lowlands and those from near the Kleszczów Graben.

Petrographic coefficients $\mathrm{O} / \mathrm{K}, \mathrm{K} / \mathrm{W}$, and $\mathrm{A} / \mathrm{B}$ have been determined according to the assumptions given by Gronkowska et al. [27]: $\mathrm{O}$ - total of sedimentary rocks $[\mathrm{LPl}+\mathrm{D}+\mathrm{S}+\mathrm{Sh}] ; \mathrm{K}-$ total of crystalline rocks $[\mathrm{Cr}+$ $\mathrm{Q}]$; $\mathrm{W}$ - total of carbonate rocks [LPl $+\mathrm{D}]$; $\mathrm{A}$ - total of non-resistant rocks $[\mathrm{LPl}+\mathrm{D}+\mathrm{Sh}]$; $\mathrm{B}$ - total of resistant rocks $[\mathrm{Cr}+\mathrm{Q}+\mathrm{S}]$.

The petrographic types of rocks are distinguished in the study, and their symbols are as follows:

- northern, Scandinavian rocks: $\mathrm{Cr}$ - crystalline (including schists); Q - quartz; LPl - Lower Paleozoic limestones; D-dolomites; S/Qt - sandstones and quartzites; Sh/ Ps - shales/Paleozoic slates;

- local rocks: L/M-limestones and marls; S-sandstones; M1 - Paleogene "older” mudstones; M2 - Neogene "younger" mudstones; Q - quartz; Fl - flints; $\mathrm{H}$ - hornstones; F - phosphatic concretions; Pt - pyrite concretions; C - lignite/brown coal.

For full interpretation of petrographic coefficients of tills, the D/LPl ratio is also used, which relates the amount of dolomite clasts to limestone clasts in the carbonate group $[3,28]$.

\subsection{Neodymium isotope ratios}

Rare earth element (metals) analysis was performed on sample Nos. 461-471, collected from deposits of the Rogowiec and Ławki Formations (see Table 4). The analyses were performed at Laboratoire Géodynamique et enregistrement Sédimentaire (PDG-REM-GM-LGS), Plouzané, France - using two methods $[29,30]$. " $\varepsilon_{\mathrm{Nd}}$ " values were used with the new Chondritic Uniform Reservoir (CHUR) 


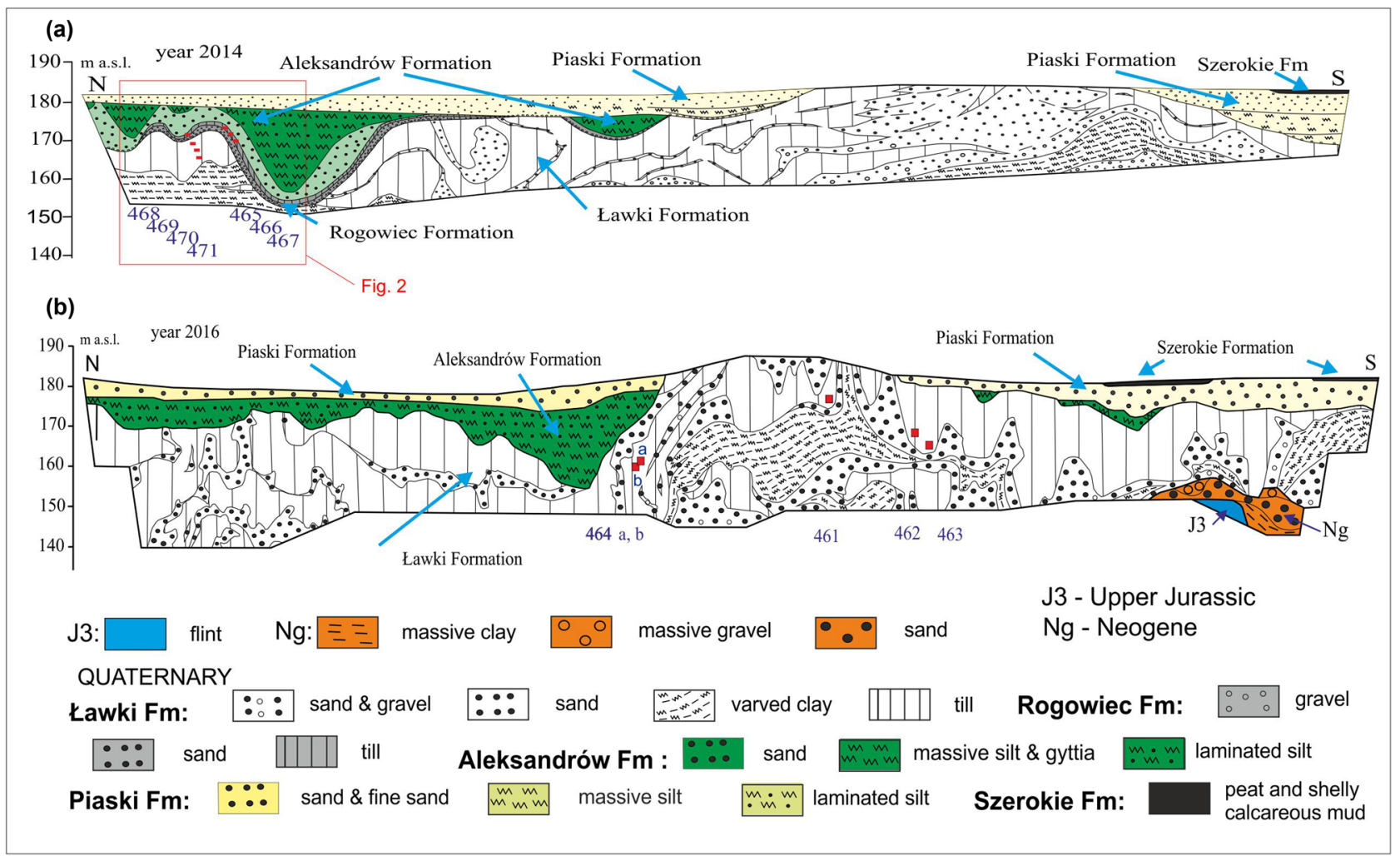

Figure 3: Geological cross-section of the quaternary sediments within the eastern part of the Szczerców outcrop (a: 2014 year, b: 2016 year).

value [29]. The ICP-MIS lab at IFREMER has started using this reference value. However, " $\varepsilon_{\mathrm{Nd}}$ ” values are commonly presented using the "old" CHUR value of Jacobsen and Wasserburg [30]. Switching between these two reference values changes the resulting " $\varepsilon_{\mathrm{Nd}}$." In the case of our data, this introduced a $-0.15 \varepsilon$-value shift. Here, we report $\varepsilon_{\mathrm{Nd}}$ values using both CHUR values [29,30].

The $\varepsilon_{\mathrm{Nd}}$ values of our studied samples were published in Boswell et al. [31]. Replicate analyses of the JNdi-1 standard solution yield an estimated measurement uncertainty of $\pm 0.3 \varepsilon$-units $(2 \sigma)$.

\subsection{Macroremnant studies}

A sample containing macrofossils (No. 464b) was collected from variously grained sands. The most frequent and common material, although difficult to examine, was organic detritus that has not been taken into consideration in microscopic analysis because the material was highly disintegrated.

First, the sample was sifted to find all, even minor, macrofossils. Then, if needed, macrofossils (or their minor fragments) were left in the mixture of glycerol and ethanol $100 \%(1: 3)$ for a few days to soften the hard tissue [32,33].
To identify the plant genera, transverse, radial, and tangential hand-made sections were cut using a razor blade. To examine anatomical (diagnostic) details of macrofossils, the sections were examined in a BX50 Olympus microscope and documented using a DP710lympus Camera cooperating with a Cell B Software (Olympus Optical Co., Poland). Greguss [34,35] and Schweingruber $[36,37]$ keys as well as a Website: InsideWood 2004 [38] were used for the identification of wood genera. Terminology was based on the IAWA list of macroscopic features for hardwood and softwood identification $[39,40]$. The digital images were processed with Macromedia Fireworks MX2004.

\section{Results}

\subsection{The main Saalian and Eemian horizons}

The Middle Polish Complex is represented by deposits of the Ławki Formation (Odranian, Older Saalian) and the Rogowiec Formation (Wartanian, Late Saalian). The Ławki Formation deposits are variable lithologically. Glaciofluvial 
sands, tills (Figure 2), locally strongly deformed glaciotectonically, and ice-dammed lake silty-sandy series have been identified [41,42]. The ice-dammed lake deposits were examined thoroughly in the "Parchliny C" site (see Figure 1) [43-45]. The sequence contained silts, clays, as well as varved clay, sometimes with extremely thick summer layers (up to $1 \mathrm{~m}$ ), dropstones, massive or laminated diamictons, and fine-grained sands (Figure 2). Black massive clay contained freshwater molluscan and ostracod species. The Ławki Formation deposits are 20-40 m thick.

The top and base of the series was erosionally truncated (Figure 3). In the south of the outcrop, the Eawki Formation deposits (tills, sands, gravels, and muds) overlie Upper Jurassic limestones (J3) and Neogene sands. They are overlain by the Wartanian Rogowiec Formation deposits - tills and glaciofluvial sands and gravels (see Figure 2).

The Rogowiec Formation deposits are represented by tills (Figure 2) and fluvioglacial/glaciofluvial sands, 10-12 $\mathrm{m}$ thick (Figure 3) [41,44], which are found at different depths (4-20 m b.g.l.; 156-175 m a.s.l. [see Figure 2]). The contact with younger deposits is locally erosional (Figure 3) and partly sedimentary. The resulting depressions in the Wartanian till (kettle holes) are filled with lacustrine deposits of the Aleksandrów Formation from the Late Saalian, Eemian Interglacial, and Early Weichselian (Table 1). The Aleksandrów Formation deposits are represented by lacustrine muds, clays, and gyttjas, as well as peats (Figure 2). They have been found in the Leśna Niwa profile [46], near the villages of Grabek-Podlas and Ścięgna-Stróża [41], as well as in the "Parchliny 2012" [47,48], "Parchliny 2014" (Figure 2) [23], and "Parchliny 2016" sections (Figure 3) [49]. These were benchmark intervals at the top of the Middle Polish Complex. The sedimentary sequence is terminated by Plenivistulian sands and muds of the Piaski Formation and Holocene sands and peats of the Szerokie Formation (Figure 3).

Profile "Parchliny 2016" (Late Wartanian to Early Eemian) is marked. Given the presence of sandy or muddy glacial rafts, the tills are suggested to be subdivided into units 1-4. This subdivision is only to indicate that the tills do not form a single stratigraphic horizon.

\subsection{Petrographic analysis of tills}

In 2014, till samples were collected near the "Parchliny 2014" section (see Figures 2 and 4 and Table 2). They came from two till horizons, separated by sands. It was found that they are characterized by high carbonate content $(40-50 \%)$ as compared to other tills [24]. Both tills 


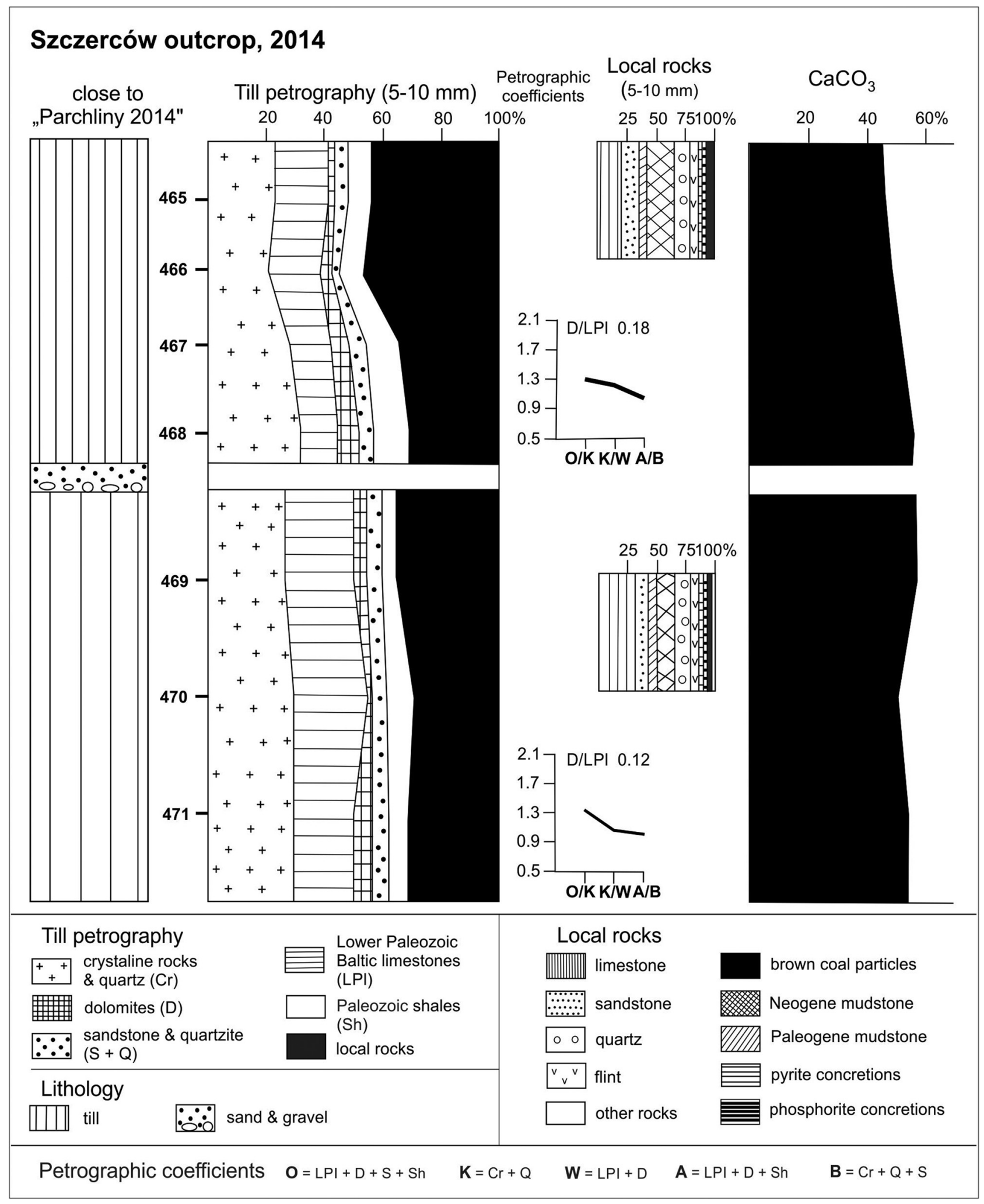

Figure 4: Results of petrographic analyses of till samples collected in 2014. 
Table 2: Petrographic coefficients $(0 / K-K / W-A / B, D / L P l)$ of the upper tills from the Szczerców outcrop, obtained in 2014

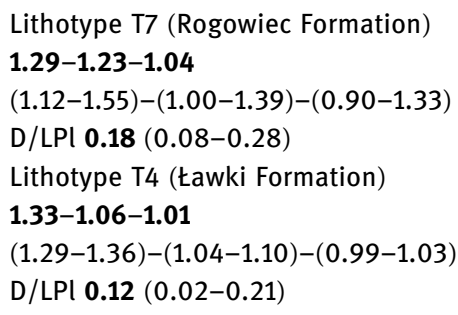

Note: A range of variation is given in brackets, in bold - mean values.

contain a considerable amount of local (24-44\%) and Scandinavian (22-35\%) rocks. The group of local rocks in the upper till is dominated by equal amounts of limestones and Neogene mudstones (ca. 20\%), whereas the lower till displays a different proportion of these rocks (limestone 30\% and Neogene mudstone 15\%). The contents of Baltic limestones and dolomites differ significantly. In the Odranian tills, the content of Baltic limestones is higher than in the Wartanian tills. The amount of dolomites, in turn, is greater in the upper tills of the Rogowiec Formation than in the Eawki Formation tills.

At the current stage of geological investigations, the upper till is tentatively correlated with lithotype T7 (Rogowiec Formation), and the lower till with lithotype T4 (Eawki Formation). This lithostratigraphic correlation is performed bearing in mind that the results of petrographic coefficients of the tills do not match those obtained a couple of years ago [24]. In a sense, this correlation is determined by the geological setting of deposits, especially those at the "Parchliny 2014" section, which are included in the Aleksandrów Formation (Figure 2).

The next till samples were acquired for analyses in 2016 (see Figure 3 and Table 3). One of them (No. 464) came from a palaeolake - from the "Parchliny 2016" site and further three samples (Nos. 461, 462, and 463) were collected more to the south, within a zone deformed glaciotectonically and tectonically. Sample Nos. 461 and 464 correspond to lithotype T4 (Ławki Formation). Given the location of sample No. 464 underneath the palaeolake (filled with the MIS6/MIS5e boundary deposits in its lower part), the Rogowiec Formation lithotypes were expected to be found. In turn, the coefficients of sample Nos. 462 and 463 are different, although the samples are taken from sites located close together, and they are also different from those recorded for sample Nos. 461 and 464. These tills were deformed, and the magnitude of the deformation is manifested by lithological variability, steep strata dips, and local high thicknesses (see Figure 3).

\subsection{Neodymium isotope ratios}

Currently, rare earth element (metals) analysis has been included in the range of till investigations. It covers the tills from sample Nos. 465-471 and 461-464 collected from deposits of the Rogowiec and Ławki Formations. For these samples, the average ${ }^{143} \mathrm{Nd} /{ }^{144} \mathrm{Nd}$ value is $0.511903(0.511852-0.511961)$ and the average $\varepsilon_{\mathrm{Nd}}$ is $-14.2(-15.2$ to -13.0$)$ (see Table 4). The mean $\varepsilon_{\mathrm{Nd}}$ signatures for the Saalian sediments are $-14.4 \pm$ $0.7(n=11)$, respectively.

The difference in $\varepsilon_{\mathrm{Nd}}$ between the sample Nos. 461-464 does not appear to have any discernible relationship with the $5-10 \mathrm{~mm}$ till petrography, as inferred from Figures 4 and 5 attachment. Given the similarity in grain size distribution of the studied samples, with pronounced modes in the coarse silt fraction, we expect that the $\varepsilon_{\mathrm{Nd}}$ signature of the tills is controlled by the provenance of heavy minerals (e.g., monazite and allanite) and not by other minerals (e.g., feldspars, pyroxenes, quartz, and clays) [50,53].

In regard to the Rogowiec samples, note that these samples cluster much more closely around the measured $\varepsilon_{\mathrm{Nd}}$ value for the Vistula River, with sample No. 467 being somewhat of an exception (more nonradiogenic).

Table 3: Petrographic coefficients (O/K-K/W-A/B, D/LPl) of tills from the Szczerców outcrop, obtained in 2016

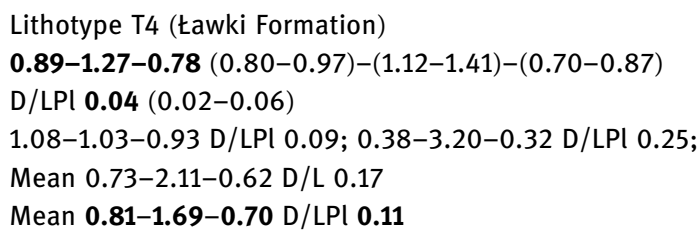




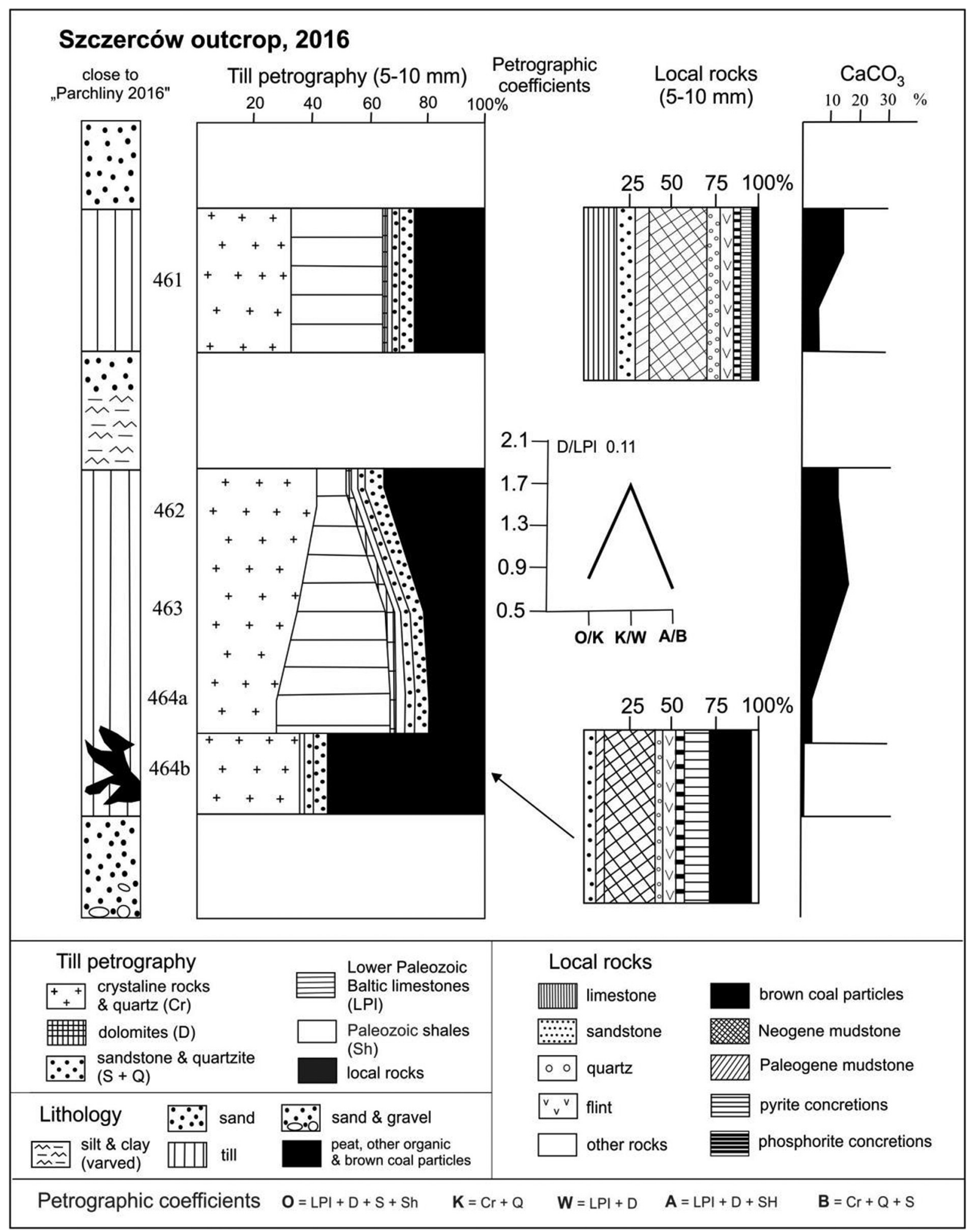

Figure 5: Results of analyses of till samples collected in 2016. 


\subsection{Results of macroremnant studies}

The main aim of the analyses of the macrofossils was the identification of the plant genera to which the wood fragments belong. Therefore, 18 woody remnants were examined.

Five of them were identified as gymnosperm wood characterized by the presence of distinct resin canals with thin-walled epithelial cells. On the radial section, the heterogeneous rays were visible, consisting of parenchyma cells and ray tracheids located on the ray margins. The characteristic large fenestriform pits, on the contact between ray parenchyma cells and axial tracheids, were also visible. These features indicate the wood as pine (Pinus) wood (Figure 6a).

The next five fragments were marked as willow wood (Salix sp.) based on the presence of the following features: (1) diffuse-porous wood with a radially arranged group of two to five vessels (Figure 6b), (2) simple perforation plate of vessel elements, (3) uniseriate rays, and (4) heterogenous rays. The last feature was recognized in a radial section, where the marginal cells of the rays with large simple pits with four to eight pits in height occurred (Figure 6c).
Three other woody macrofossils were identified as a birch (Betula sp.) wood. This genus is characterized by diffuse-porous wood with a radially arranged group of three to five vessels (or more); the scalariform perforation plates in the vessels elements (Figure 6d) and bi-tetraseriate rays (Figure 6e). Five macrofossils could not be identified. They were fragments of young stems of dicotyledonous trees, 1-2 years old, and heavily compressed.

\section{Discussion}

The results of the research conducted in the Szczerców outcrop supplement the data on the Pleistocene section in central Poland (Table 1). Although no continuous horizons of organic sediments have been found in the Czyżów Formation (Czyżów Complex, Holsteinian/Ferdynandovian [see Table 1]), the studies of macroremains from the bottom of the Middle Polish Complex helped to determine the lower limit of the Saalian complex (see also [54,55]). The investigated sandy deposits contained macroremains that originated in the valley bottom environment. The deposits are
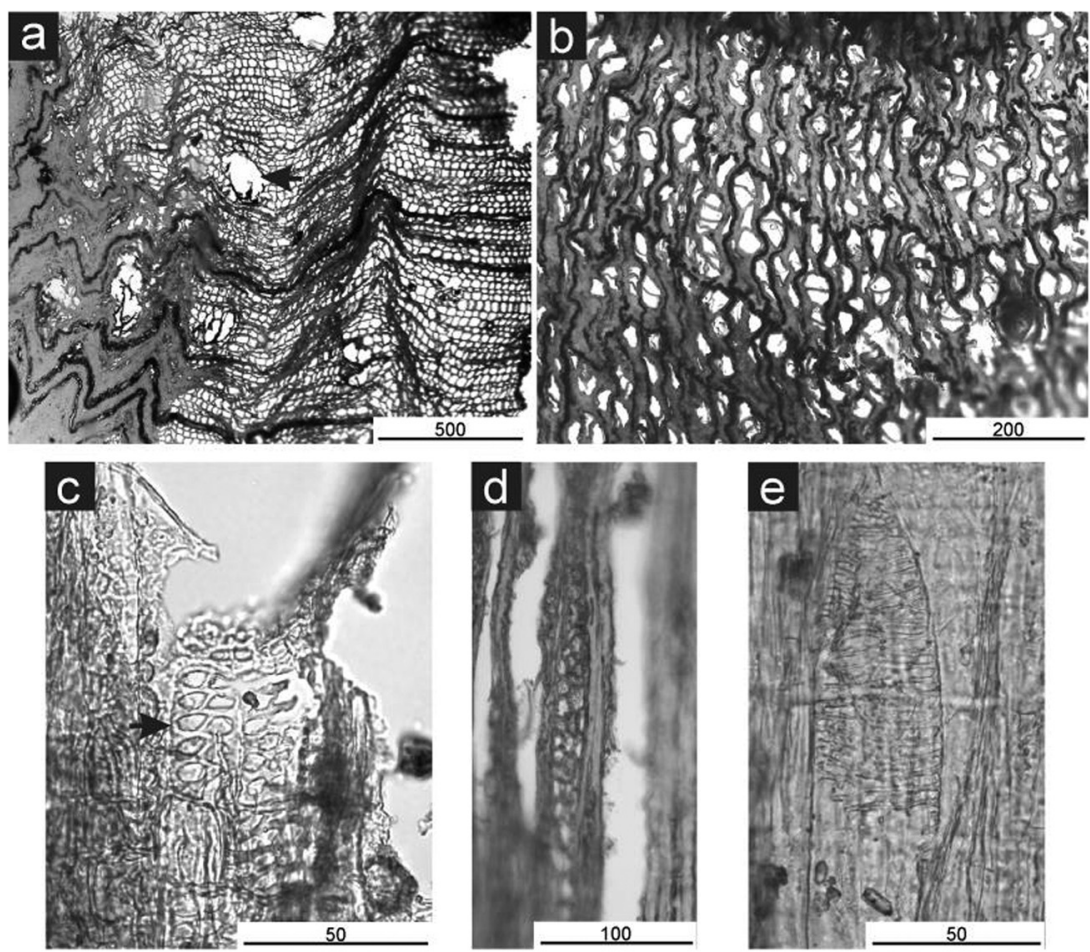

Figure 6: The anatomical features of the woody macrofossils. (a) Transverse section of Pinus wood; the resin canals with thin-walled epithelial cells occur (arrows). Hardly compressed wood is visible on the left side of the image. (band c) Salix sp. wood; (b) diffuse-porous wood with a radially arranged group of two to five vessels shown in transverse section; (c) marginal cell of the ray with large simple pits (arrow) between the ray and vessel shown in radial section; usually four to eight pits in height occur in the upright, marginal cell of the heterogeneous ray; ( $d$ and e) Betula sp. wood; (d) tangential section showing a triseriate ray; (e) scalariform perforation plates are presented in radial section. Scale bar in $\mu \mathrm{m}$. 
compressed probably as a result of the pressure of overburden strata and compaction. They form a discontinuous horizon and overlie both the Neogene deposits and probably the partially preserved sandy deposits of the South Polish Glaciations. Their stratigraphic position and preserved remains of deciduous and coniferous trees are ambiguous. The deposits might have been accumulated in both the Pliocene and the interglacials or interstadials of the Lower or Middle Pleistocene (Czyżów or Łękińsko formations). They were extensively described in the nearby Betchatów [1]. The sandy deposits with macroremains are covered by relatively thick sandy and loamy sediments (Figure 3).

The Middle Polish Complex (Saalian) starts with the Ławki Formation deposits. In the study area, muddy-clay series and a single till horizon (lithotype T4) were found in 2014-2016. The till is strongly deformed and rests on Jurassic, Neogene, and Early Pleistocene deposits (Figure 3). In the Bełchatów outcrop, like in the Szczerców outcrop, these deposits were strongly deformed. In the nearby Bełchatów mine field, they were found at the top of the lower structural level, disturbed as a result of tectonic processes [1]. The deposits investigated in the Szczerców outcrop may have been deformed because of tectonic Chabielice fault (which uplifted Jurassic limestone), glaciotectonic (on time of the advancing Wartanian ice sheet), and halotectonic factors (i.e., DSD).

The $\varepsilon_{\mathrm{Nd}}$ values of the studied Saalian tills are also compared to 15 samples obtained from the Greater Poland region, collected from glacial or glaciofluvial deposits accumulated during the last glacial maximum (LGM) [51]. Compare the $\varepsilon_{\mathrm{Nd}}$ of these Szczerców tills with: (1) sediments from the mouth of the Vistula River $(-14.3 \pm 0.3,2 \sigma)$ and (2) Weichselian glacigenic sediments from Poland $(-15.1 \pm 0.8, n=15,2 \sigma)$. Samples 461 and 463 are more radiogenic (younger in the $\mathrm{Sm} / \mathrm{Nd}$ sense) than any of the 15 samples.

For these samples, the average ${ }^{143} \mathrm{Nd} /{ }^{144} \mathrm{Nd}$ value is $0.511855(0.511792-0.511921)$, and the average for $\varepsilon_{\mathrm{Nd}}$ is $-15.2(-16.5$ to -13.9$)$. The Rogowiec samples are not glaciotectonically disturbed. These samples display a similar relationship between $\varepsilon_{\mathrm{Nd}}$ and grain size as the Weichselian samples used by Boswell et al. [52] to infer sediment transport distances by the Baltic Ice Stream. It is plausible that this relationship could hold for the Saalian Baltic Ice Stream(s) as well as the findings of Boswell et al. [31].

The $\varepsilon_{\mathrm{Nd}}$ values of the studied Saalian tills are also compared to samples from the Greater Poland region, collected from glacial or glaciofluvial deposits accumulated during the LGM $(-15.1 \pm 0.8, n=15,2 \sigma)$ and the mouth of the Vistula River $(-14.3 \pm 0.3,2 \sigma)$ [51]. Analysis of $\varepsilon_{\mathrm{Nd}}$ values within the studied sections reinforces our lithostratigraphic correlations and reflects the differences in disturbance between the Eawki and Rogowiec Formation tills.

Samples 461 and 463 are more radiogenic (younger in the $\mathrm{Sm} / \mathrm{Nd}$ sense) than any of the 15 Polish samples analyzed by Toucanne et al. [51]. This $2 \varepsilon$-unit difference between samples 461/463 and 462/464 evinces a lack of homogenization of the Eawki Formation till at this site. Because the samples are disturbed, it is possible that samples 461 and 463 have incorporated relatively radiogenic fine sediments (silts and clays) from an unidentified, presumably local source inconsistent with the expected signature of glacigenic sediments from the Weichselian glaciation (LGM) $(-15.1 \pm 0.8, n=15,2 \sigma)$ or the Vistula river background $(-14.3 \pm 0.3,2 \sigma)$.

The Rogowiec tills are not disturbed in the Szczerców outcrop, and this is reflected in the dispersion of these samples' $\varepsilon_{\mathrm{Nd}}$ values. The standard deviation in the $\varepsilon_{\mathrm{Nd}}$ of the Rogowiec samples (both Early and Late Saalian, but also separately) is much less than for the Szczerców (i.e., \pm 0.36 vs \pm 1.15 ). The increased dispersion in $\varepsilon_{\mathrm{Nd}}$ of the Eawki Formation tills reflects their disturbed (tectonically, glaciotectonically, or halotectonically) nature and is likely explained by the incorporation of radiogenic fine sediments of local provenance.

The undisturbed Rogowiec samples display a similar relationship between $\varepsilon_{\mathrm{Nd}}$ and grain size as the Weichselian samples used by Boswell et al. [52] to infer sediment transport distances by the Baltic Ice Stream. It is plausible that this relationship could hold for the Saalian Baltic Ice Stream(s) as well [31]).

The Eawki Formation deposits are erosionally overlain by the Rogowiec Formation deposits of the Wartanian Stadial. Three till horizons (lithotypes T7, T6, and T5) have been identified in the Bełchatów outcrop and included in the Rogowiec Formation. One lithotype of till from this formation, most likely $\mathrm{T} 7$, has been recognized so far in the Szczerców outcrop. Initial soil horizons have also been identified within the Rogowiec Formation in the Bełchatów outcrop. This would suggest longer breaks in glacial deposition and even decay of the ice sheet over a larger area, so that the conditions allowing soil-forming processes could take place. In the Bełchatów outcrop, these tills are not deformed. Wherever there are any disturbances, they are visible only in the basal till (T5) and are represented by deformation resulting from the stress of the advancing Wartanian ice sheet [8]. In the case of the till filling the Kleszczów Graben in the western sector, there are various types of deformation (see Figure 3) of different origins, like in the case of the Eawki Formation deposits. In the hinterland and foreland of both outcrops, there is a single till horizon of the Wartanian Stadial/Glacial. In 
depressions, the Wartanian sands and tills overlie lacustrine gyttjas and peats of the Eemian Interglacial.

In the "Parchliny 2012" [47], "Parchliny 2014" [48], and "Parchliny 2016" [49] sections, Eemian Interglacial deposits, deposited as a result of lake basins infilling with terrigenous sediments, have been identified. Organic deposits were of key importance for determining the lithostratigraphic position of the underlying tills. The "Parchliny 2014" and "Parchliny 2016" sections also encompass the MIS6/MIS5e and MIS5e/MIS5dcba transitions. These palaeolakes developed at the end of MIS 6, later they were probably connected by subglacial channels, and even later partly used by flowing waters and transformed by them [22]. This was the case with the Krasówka stream, whose "valley" is too large compared to its catchment area. Some of these studies are still underway, but it may turn out that Lower Vistulian deposits, previously unknown in this area ("Parchliny 2014" site), will be found.

\section{Conclusions and recommendations}

1. Organic horizons defining the boundaries of Saalian deposits have been found - at the base, macroremains of trees in sediments of unclear stratigraphic position (Pliocene, the Lower Pleistocene Łękińsko Formation or the Czyżów Formation (with Czyżów Interstadial; Holsteinian). At the top, there are gyttjas and peats of the Aleksandrów Formation (Late Saalian, Eemian, Early Weichselian), which accumulated in depressions of the Wartanian surface.

2. The Saalian deposits are represented by clay-muddy and sand-gravelly sediments and two till beds T4 and T7 corresponding to the Odranian (Eawki Formation) and the Wartanian (Rogowiec Formation). These tills are strongly disturbed. The possibility of deformation as a result of tectonics within the Kleszczów Graben (Chabielice fault), salt tectonics of the DSD, and glaciotectonics is pointed out.

3. Lithopetrographic studies and rare earth element (metals) analyses helped distinguish the features of these tills, wherever deformed, and compare them with similar ones examined in central Poland. The petrographic coefficients for lithotype T4 (Eawki Formation) are 1.33-1.06-1.01 and 0.12 (2014) and 0.81-1.690.70 and 0.11 (2016), and for lithotype T7 (Rogowiec
Formation) these are 1.29-1.23-1.04 and 0.12 (2014) and $0.89-1.27-0.78$ and 0.04 (2016). Investigations of the Nd isotopic compositions of the studied samples allow reinterpreting of till deformation and tentative lithostratigraphic correlations. Neodymium isotope ratios prove that $\varepsilon_{\mathrm{Nd}}$ values less than -12.4 reflect the southern Fennoscandian Ice Sheet sediment provenance, but $\varepsilon_{\mathrm{Nd}}$ values greater than -12.4 indicate western European origin. "P” $(-14.4 \pm 0.7)$ and "D" $(-12.4 \pm$

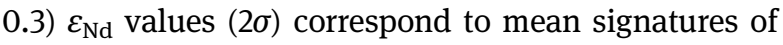
Saalian glacigenic moraine sediment from Poland and Denmark, respectively.

4. The authors believe that in the future more emphasis should be placed on the study of tills. As the mining operations are in progress, this work has to be coordinated with the analysis of geological and mining sketches of walls of the Szczerców outcrop. As the mining works are getting closer to the DSD, the deformation of Pleistocene formations is expected to be greater. Only the combined data resulting from both lithopetrographic studies of the tills and analysis of their distribution in the vertical section (cross-sections analyzed in time) can bring us a better picture of the changes that occurred in the past.

5. Perhaps the issue of stratigraphic subdivision of the Saalian tills in both outcrops should be considered another way. When studying the Pleistocene formations, a relatively complete section is assumed to occur here, because the Kleszczów Graben is treated as a kind of trap that was to preserve this section. However, if this assumption were put aside, it would seem that the two major glacials, which have left behind the four till horizons, must have been separated by at least one interglacial, although no interglacial deposits have been preserved. This could have been the result of processes of glacial exaration, glaciotectonics, and erosion of glacial and river waters.

Acknowledgments: Cordial thanks are directed to Dr Samuel Toucanne for examination of the samples at Laboratoire Géodynamique et enregistrement Sédimentaire (PDG-REMGM-LGS). The authors also thank the Management of the Bełchatów Lignite Opencast Mine for making it possible to study the Pleistocene deposits in the period from 2009 to 2017. Finally, geologists Marek Jończyk, Anna Skórzak, Katarzyna Kowalska, and Adam Kucia are thanked for technical and substantive assistance. The authors thank the three anonymous reviewers for valuable comments. 


\section{References}

[1] Krzyszkowski D. Czwartorzęd rowu Kleszczowa. Litostratygrafia i tektonika (Quaternary of the Kleszczów Graben. Lithostratigraphy and Tectonics - in Polish, summary in English). Studia Geograficzne. t. LIV. Wroctaw: Wydawnictwo Uniwersytetu Wroctawskiego; 1992.

[2] Czerwonka JA, Krzyszkowski D. Till characteristics and stratigraphy in the Kleszczów Graben (Central Poland). Quaternary Stud Pol. 1992;11:43-64.

[3] Czerwonka JA. Litostratygrafia glin lodowcowych: uwagi metodyczne (Lithostratigraphy of glacial tills: methodological notes - in Polish, summary in English). Biul Państwowego Instytutu Geologicznego. 1998;385:113-25.

[4] Allen P, Krzyszkowski D. Till base deformation and fabric variation in lower Rogowiec (Wartanian, Younger Saalian) till, Betchatów outcrop, central Poland. Ann Soc Geol Pol. 2008;78(1):19-35.

[5] Krzyszkowski D, Wachecka-Kotkowska L, Wieczorek D, Stoiński A. Petrography of glacial tills in the Szczerców Outcrop, Central Poland - problems of stratigraphic interpretation. Stud Quaternaria. 2015;32(2):99-108.

[6] Lindner L, Marks L, Nita M. Climatostratigraphy of interglacials in Poland: Middle and Upper Pleistocene lower boundaries from a Polish perspective. Quaternary Int. 2013;292:113-23. doi: 10.1016/j.quaint.2012.11.018.

[7] Marks L, Dzierżek J, Janiszewski R, Kaczorowski J, Lindner L, Majecka A, et al. Quaternary stratigraphy and palaeogeography of Poland. Acta Geol Polonica. 2016;66(3):403-27.

[8] Marks L, Bińka K, Woronko B, Majecka A, Teodorski A. Revision of the late Middle Pleistocene stratigraphy and palaeoclimate in Poland. Quaternary Int. 2019;534:5-17. doi: 10.1016/ j.quaint.2019.02.023.

[9] Hałuszczak A. Cenozoic dynamics of the Dębina Salt Dome, Kleszczów Grabem, inferred from structural features of the Tertiary-Quaternary cover. Ann Soc Geol Pol. 2004;74(3):311-8.

[10] Wieczorek D, Stoiński A, Krzyszkowski D, WacheckaKotkowska L, Krzymińska J. The results of new studies of Quaternary sediments in the Kleszczów Graben, Szczerców Outcrop, Betchatów Lignite Opencast Mine. Landf Anal. 2015;29:63-71.

[11] Marks L, Ber A, Gogotek W, Piotrowska K, (eds.). Mapa geologiczna Polski w skali 1:500,000. (Geological Map of Poland 1:500,000 - in Polish). Warszawa: MŚ \& PIG; 2006.

[12] Turkowska K. Geomorfologia regionu tódzkiego (Geomorphology of the tódź Region - in Polish). Wrocław: Wydawnictwo Uniwersytetu Łódzkiego (Łódź University Press); 2006. p. 237.

[13] Wachecka-Kotkowska L. Rozwój rzeźby obszaru między Piotrkowem Trybunalskim, Radomskiem a Przedborzem w czwartorzędzie (Development of land relief between Piotrków Trybunalski, Radomsko and Przedbórz in the Quaternary - in Polish, summary in English). Wroctaw: Wydawnictwo Uniwersytetu Łódzkiego (Łódź University Press); 2015. p. 128.

[14] Baraniecka MD, Sarnacka Z. Stratygrafia czwartorzędu i paleogeografia dorzecza Widawki. Z badań czwartorzędu w Polsce (Quaternary stratigraphy and paleogeography of the Widawka River basin. Quaternary research in Poland - in Polish, summary in English). Biul Inst Geol. 1971; 254(13):157-269.
[15] Lindner L, Marks L. O podziale klimatostratygraficznym kompleksu środkowopolskiego w plejstocenie Polski (On the climate stratigraphy division of the Middle Polish Complex in the Pleistocene of Poland - in Polish, summary in English). Przegląd Geologiczny. 2012;60(1):36-45.

[16] Domostawska-Baraniecka MD, Skompski S. Deglacjacja lobu Widawki (Deglaciation of the Widawka Lobe - in Polish, summary in English). Kwartalnik Geologiczny. 1967;11(3):707-30.

[17] Wachecka-Kotkowska L. Badania ułożenia klastów w glinach morenowych jako element rekonstrukcji kierunków transportu lodowego w obszarze między Piotrkowem Trybunalskim, Radomskiem a Przedborzem (Directional characteristics of tills forming the plateau in the Piotrków Trybunalski, Radomsko and Przedbórz area - in Polish, summary in English). Acta Geograph Lodziensia. 2015;103:99-111.

[18] Gotowała R, Hałuszczak A. The Late Alpine structural development of the Kleszczów Graben (Central Poland) as a result of reactivation of the pre-existing, regional dislocations. EGU Stephan Mueller Spec Publ Ser. 2002;1:137-50.

[19] Krzyszkowski D. Odranian glaciolacustrine sedimentation in the Kleszczów Graben, central Poland. Ann Soc Geol Pol. 1994;64(1-4):1-14.

[20] Krzyszkowski D. An outline of the Pleistocene stratigraphy of the Kleszczów Graben, Central Poland. Quaternary Sci Rev. 1995;14:61-83.

[21] Goździk J, Zieliński T. Evolution of Early Pleistocene fluvial systems in central Poland prior to the first ice sheet advance - a case study from the Betchatów lignite mine. Geologos. 2017;23(2):89-107. doi: 10.1515/logos-2017-0011.

[22] Wachecka-Kotkowska L, Krzyszkowski D, Klaczak K, Król E. Middle Weichselian Pleniglacial sedimentation in the Krasówka river palaeovalley, central Poland. Ann Soc Geol Pol. 2014;84(4):323-40.

[23] Wachecka-Kotkowska L, Krzyszkowski D, Malkiewicz M, Mirosław-Grabowska J, Niska M, Krzymińska J, et al. An attempt to reconstruct the late Saalian to Plenivistulian (MIS6MIS3) natural lake environment from the "Parchliny 2014" section, central Poland. Quaternary Int. 2018;467:5-25.

[24] Krzyszkowski D, Wachecka-Kotkowska L, Raczyk J, Wieczorek D, Stoiński A. Petrografia górnych glin zwałowych z odkrywki Szczerców KWB Betchatów w świetle badań z 2014 i 2015 r. (Petrography of upper tills from the Szczerców outcrop KWB Betchatów in the light of research from 2014 and 2015 - in Polish). In: Kordowski J, Lamparski P, Lisicki S, Roman M, (eds.). XXII Konf. Naukowo-Szkoleniowa, Stratygrafia plejstocenu Polski, "Plejstocen Kotliny Płockiej oraz postglacjalna transformacja jej rzeźby”, 31.0804.09.2015 r. Gołaszewo. Warszawa: Państwowy Instytut Geologiczny; 2015. p. 37-39.

[25] Krzyszkowski D, Wieczorek D, Wachecka-Kotkowska L, Raczyk J, Toucanne S. Stratygrafia glin w odkrywce Szczerców (Till stratigraphy in the Szczerców outcrop - in Polish). In: Twardy J, (ed.). XXIV Konferencja Naukowo-Szkoleniowa, Stratygrafia plejstocenu Polski, “Czwartorzęd pogranicza niżu i wyżyn w Polsce Środkowej”, 4-8.09.2017 r. Wawrzkowizna k/ Bełchatowa, Państwowy Instytut Geologiczny Warszawa. Łódź: Łodź University Press; 2017. p. 128-32.

[26] Marks L, Ber A, (eds.) Metodyka opracowania Szczegółowej Mapy Geologicznej Polski w skali 1:50,000 (Methodology for 
developing a Detailed Geological Map of Poland on a scale of 1:50,000 - in Polish). Warszawa: PIG; 1999.

[27] Gronkowska B, Kenig K, Rzechowski J. Petrografia glin zwatowych Podlasia i Mazowsza (Petrography of the Mazovia and Podlasie Region - in Polish). 1968. Manuscript, NAG PIG-PIB Warszawa.

[28] Krzyszkowski D. Stratygrafia, petrografia i paleografia glin lodowcowych w rejonie pótnocno-zachodniego wybrzeża Polski (Stratigraphy, petrography and paleography of glacial tills in the region of the north-west coast of Poland - in Polish, summary in English). Biul Państwowego Inst Geol. 2010;438:51-92.

[29] Bouvier A, Vervoot JD, Patchett PJ. The Lu-Hf and isotopic composition of CHUR: constraints from unequilibrated chondrites and implications for the bulk composition of terrestrial planets. Earth Planet Sci Lett. 2008;273:48-57.

[30] Jacobsen SB, Wasserburg GJ. Sm-Nd Isotopic Evolution of Chondrites. Earth Planet Sci Lett. 1980;50:139-55.

[31] Boswell SM, Toucanne S, Pitel-Roudau M, Creyts TT, Eynaud F, Bayon G. Enhanced surface of the Fennoscandian ice sheet during periods of North Atlantic cooling. Geology. 2019;47(7):664-8. doi: 10.1130/G46370.1.

[32] Myśkow E. Procambium-cambium transition during vascular meristem development in Diospyros lotus. Botany. 2010;88:985-93.

[33] Myśkow E, Zagorska-Marek B. Dynamics of the ray pattern in cambium of Diospyros lotus. Dendrobiology. 2013;69:21-30.

[34] Greguss P. The identification of Central-European dicotyledonous trees and shrub based on xylotomy. Budapest: Hungarian Museum of Natural History; 1945.

[35] Greguss P. Identification of living gymnosperms on the basis of xylotomy. Budapest: Akademiai Kiado; 1955.

[36] Schweingruber FH. Microscopic wood anatomy. Structural variability of stems and twigs in recent and subfossil woods from Central Europe. Birmensdorf: Swiss Federal Institute of Forestry Research; 1978.

[37] Schweingruber FH. Anatomy of European Woods: An Atlas for the Identification of European Trees, Shrubs and Dwarf Shrubs. Bern und Stuttgart: Eidgenössische Forschungsanstalt für Wald Schnee und Landschaft Haupt; 1990.

[38] InsideWood, 2004-onwards, 2004. [on-line:] http:// insidewood.lib.ncsu.edu/search.

[39] IAWA Committee. IAWA list of microscopic features for hardwood identification: with an appendix on non-anatomical information. IAWA Bull. 1980;10(3):219-332.

[40] IAWA Committee. IAWA list of microscopic features for softwood identification. IAWA J. 2004;25(1):1-70.

[41] Król J, Hałuszczak A, Dobosz T. Dokumentowanie profili geologicznych z odstonięć KWB Betchatów i KWB Konin etap I (obejmujący część pilotażową). I Rejon KWB Betchatów, odkrywka Szczerców (Documenting geological profiles from the walls of the KWB Betchatów and KWB Konin stage I (including the pilot part). I District of KWB Betchatów, Szczerców outcrop - in Polish, documentary file); 2007. Manuscript, NAG PIG-PIB Warszawa.

[42] Kurpiewska I. Pozycja i wyksztatcenie osadów zastoiskowych odsłoniętych w wyrobisku Pola Szczerców (Rów Kleszczowa, niż polski) (Position and development of the sediments exposed in the Szczerców Field excavation (Kleszczów Graben, Polish Lowland - in Polish). In: Marks L, Pochocka-Szwarc K, editors. XVII Konf. Stratygrafia plejstocenu Polski, “Dynamika zaniku lądolodu podczas fazy pomorskiej w północnowschodniej części Pojezierza Mazurskiego”, 6-10.09.2010. Jeziorowskie. Warszawa: PIG-PIB Warszawa Press; 2010. p. 131.

[43] Wachecka-Kotkowska L, Krzyszkowski D, Krzymińska J. Climatic control on Saalian glacilacustrine sedimentation in the Kleszczów Graben, Central Poland, Case of the tawki Formation. In: INQUA-SEQA 2012 Meeting, at the edge of the sea: sediments, geomorphology, tectonics and stratigraphy in Quaternary studies. 26-30th, September 2012. Sassari, Sardinia, (Italy); 2012. p. 101-2.

[44] Wachecka-Kotkowska L, Krzyszkowski D, Krzymińska J, Drzewicki W, Wieczorek D, Stoiński A. Geneza, litologia i stratygrafia osadów czwartorzędowych rowu Kleszczowa w świetle nowych badań w odkrywce Szczerców (Genesis, lithology and stratigraphy of the Quaternary sediments of the Kleszczów ditch in the light of new research in the Szczerców outcrop - in Polish). In: Kostrzewski A, Rachlewicz G, Woszczyk M, editors. VI Seminarium Geneza, litologia i stratygrafia utworów czwartorzędowych, 14-15.11.2013 r. Poznań; 2013. p. 168-72.

[45] Wachecka-Kotkowska L, Krzyszkowski D, Krzymińska J, Drzewicki W, Jędrysek M-O. Short-term changes in a Saalian glacial lake - the Parchliny C site, central Poland. Catena. 2017;157:299-309. doi: 10.1016/j.catena.2017.05.004.

[46] Janczyk-Kopikowa Z. Analiza pyłkowa nowych stanowisk interglacjału eemskiego z dorzecza Widawki (Pollen analysis of new Eem Interglacial sites from the Widawka basin - in Polish, summary in English). Biul Inst Geol. 1971;254:65-88.

[47] Wachecka-Kotkowska L, Krzyszkowski D, Drzewicki W. Development of the Eemian palaeolake in the Kleszczów Graben, Szczerców Field, Belchatów Outcrop, Central Poland. In: International Field Symposium, Palaeolandscapes from Saalian to Weichselian, South Eastern Lithuania. June 25-30, 2013, Vilnius-Trakai, Lithuania. Abstracts. 2013. p. 103-4.

[48] Wieczorek D, Stoiński A. Szczegółowa mapa geologiczna Polski w skali 1:50 000, ark. Szczerców (735) wraz z objaśnieniami. Reambulacja (Detailed Geological Map of Poland on a scale of 1:50,000, Szczerców sheet (735) with explanations. Reworks - electronical document in Polish). Warszawa: Ministerstwo Środowiska; 2019.

[49] Wachecka-Kotkowska L, Krzyszkowski D, MirostawGrabowska J, Niska M, Majecka A, Wieczorek D, et al. Schyłek zlodowaceń środkowopolskich i początek interglacjału emskiego w świetle badań multiproxy, stanowisko "Parchliny 2016", Polska Środkowa (The decline of the Middle Polish Glaciations and the beginning of the Eemian Interglacial in the light of multiproxy research, "Parchliny 2016" site, Central Poland - in Polish). In: Twardy J, editor. XXIV Konferencja Naukowo-Szkoleniowa, Stratygrafia plejstocenu Polski “Czwartorzęd pogranicza niżu i wyżyn w Polsce Środkowej”, 48.09.2017 r. Wawrzkowizna k/Betchatowa, Państwowy Instytut Geologiczny Warszawa. Łódź: Łodź University Press; 2017. p. 40-48.

[50] Tanaka T, Togashi S, Kamioka H, Amakawa H, Kagami H, Hamamoto T, et al. Ndi-1: a neodymium isotopic reference in consistency with La Jolla neodymium. Chem Geol. 2000;168:279-81.

[51] Toucanne S, Soulet G, Freslon N, Jacinto RS, Dennielou B, Zaragosi S, et al. Millennial-scale fluctuations of the European 
Ice Sheet at the end of the last glacial, and their potential impact on global climate. Quaternary Sci Rev. 2015;123:113-33. doi: 10.1016/j.quascirev.2015.06.010.

[52] Boswell SM, Toucanne, SCreytsTT, Hemming. Continentalscale transport of sediments by the Baltic Ice Stream elucidated by coupled grain size and $\mathrm{Nd}$ provenance analyses. Earth Planet Sci Lett. 2018;490:143-50.

[53] Garcom M, Chauvel C, France-Lanord Ch, Limonta M, Garzanti E. Which minerals control the $\mathrm{Nd}-\mathrm{Hf}-\mathrm{Sr}-\mathrm{Pb}$ isotopic compositions of river sediments. Chem Geol. 2014;364:42-55.

[54] Myśkow E, Krzyszkowski D, Wachecka-Kotkowska L. Makroskopowe szczątki roślin z mezoplejstoceńskich osadów odkrywki Szczerców KWB Betchatów (Macroscopic plant remains from Mesopleistocene sediments of the Szczerców outcrop KWB Betchatów in Polish). In: Dzieduszyńska D, Roman M, editors. VII Konferencja Paleobotaniki Czwartorzędu, “Dynamika zmian roślinności Niżu Polskiego w dobie późnoglacjalnych zmian klimatu i narastania antropopresji w holocenie", 10-12.06.2015 r. tódź: Uniwersytet tódzki; 2015. p. 45-47.

[55] Myśkow E, Krzyszkowski D, Wachecka-Kotkowska L, Wieczorek D. Plant macrofossils from Czyżów Complex deposits of the Szczerców outcrop, central Poland. Geol Geophys Environ. 2016;42(3):325-36. 